\title{
Leaf anatomy is associated with the type of growth form in Neotropical savanna plants
}

\author{
Davi R. Rossatto, Rosana M. Kolb, and Augusto C. Franco
}

\begin{abstract}
Scleromorphic leaf structures are associated with plants growing under drought-prone conditions, high irradiances, and nutrient-poor soils. Sclerophylly can also be a valuable deterrent against herbivores. However, comprehensive studies of leaf anatomical traits encompassing different growth forms are lacking. The savannas of central Brazil (Cerrado) are characterized by high species diversity and a variety of growth forms. We performed a field study to characterize leaf anatomical traits and leaf mass per area (LMA) in 57 co-occurring Cerrado species of distinct plant families (located at different positions in the angiosperm phylogeny) and categorized according to the following growth forms: trees, palms, shrubs, subshrubs, vines, grasses and herbs. Plant growth form and leaf structure were interrelated. Four groups with distinct leaf anatomical syndromes were identified by NMDS analysis: grasses, palms, herbaceous (herbs, vines, and most subshrubs), and woody (trees and shrubs) plants. Trees and shrubs had scleromorphic dorsiventral leaves, with high tissue thickness and LMA. Herbaceous plants had thin, mesomorphic leaves. While most herbaceous plants had dorsiventral type of mesophyll, grasses and palms had homogenous mesophyll with sclerenchymatous bundle sheath extensions. Palms differed from grasses by having thicker leaves and sclerenchymatous hypodermis. In conclusion, Neotropical savannas cannot be exclusively described as scleromorphic vegetation.
\end{abstract}

Key words: Cerrado, growth forms, leaf anatomy, LMA, NMDS analysis.

Résumé : Les structures foliaires scléromorphiques sont associées aux plantes qui poussent sous des conditions sujettes à la sécheresse, à un éclairement énergétique par rayonnement solaire élevé et à des sols pauvres en nutriments. La sclérophyllie peut aussi constituer un précieux moyen de dissuasion envers les herbivores. Cependant, des études exhaustives des traits anatomiques foliaires englobant différentes formes de croissance sont absentes. Les savanes du centre du Brésil (Cerrado) se caractérisent par une haute diversité en espèces et une variété de formes de croissance. Les auteurs ont réalisé une étude sur le terrain afin de caractériser les traits anatomiques foliaires et la masse foliaire par unité de surface chez 57 espèces co-occurrentes de familles distinctes du Cerrado (situées à différentes positions de la phylogénie des angiospermes) et catégorisées en fonction des formes de croissance suivantes : arbres, palmiers, arbustes, sous-arbrisseau, lianes ou plantes grimpantes, graminées et herbes. Les formes de croissance des plantes et la structure foliaire étaient inter-reliées. Quatre groupes possédant des traits anatomiques foliaires observables distincts ont été identifiés par analyse multidimensionnelle non métrique : herbes, palmiers, herbacées (graminées, lianes ou plantes grimpantes et la plupart des sousarbrisseaux) et végétaux ligneux (arbres et arbustes). Les arbres et les arbustes possédaient des feuilles scléromorphiques dorsiventrales, à épaisseur tissulaire et masse foliaire par unité de surface élevées. Les plantes herbacées possédaient des feuilles mésomorphiques minces. Alors que la plupart des plantes herbacées présentaient un mésophylle de type dorsiventral, les herbes et les palmiers avaient un mésophylle homogène possédant des extensions sclérenchymateuses de gaine périvasculaire. Les palmiers différaient des herbes par des feuilles plus épaisses et un hypoderme sclérenchymateux. En conclusion, les savanes néotropicales ne peuvent pas être exclusivement décrites en tant que végétation scléromophique. [Traduit par la Rédaction]

Mots-clés : Cerrado, forme de croissance, anatomie foliaire, masse foliaire par unité de surface, analyse multidimensionnelle non métrique.

Received 5 January 2015. Accepted 2 June 2015.

D.R. Rossatto. Departamento de Biologia, Faculdade de Ciências Agrárias e Veterinárias, Univ. Estadual Paulista, Via de Acesso Prof. Paulo Donato Castellane s/n, 14884-900, Jaboticabal, SP - Brazil.

R.M. Kolb. Departamento de Ciências Biológicas, Faculdade de Ciências e Letras, Univ. Estadual Paulista, Av. Dom Antonio 2100, 19806-900, Assis, SP - Brazil.

A.C. Franco. Departamento de Botânica, Instituto de Ciências Biológicas, Universidade de Brasília, Caixa Postal 04457, 70904-970, Brasília, DF - Brazil.

Corresponding author: Davi R. Rossatto (e-mail: drrossatto@gmail.com). 


\section{Introduction}

Savannas are widespread in tropical and subtropical regions, and consist of a variable mixture of trees and grasses (Bourliere 1983). Seasonal water stress, fire, and herbivory are the most significant factors affecting plant population persistence, selecting for specific traits across tropical savannas (Lehmann et al. 2014). However, depending on the savanna type and the region of the world they occur, biotic or abiotic filters may predominate in determining which morpho-functional strategies would be successful (Lehmann et al. 2014). In South America, abiotic factors such as nutrient-poor soils with high levels of aluminum, high irradiances, seasonal water deficit (Franco 2002), and fire prevail (Hoffmann 1996); biotic factors are mainly related to herbivory caused by insects (Marquis et al. 2001; Costa et al. 2008). In contrast, herbivory and trampling by large mammals in combination with fire are the major filters affecting African savanna plants (Asner et al. 2009).

Fire and seasonal drought select for leaf strategies that allow rapid growth (especially for small plants) during the wet season (e.g., leaves with low leaf dry mass per area and high amount of photosynthetic tissue), as well as leaves with short life cycles (Keeley et al. 2011). In contrast, soil oligotrophy selects for leaf anatomical traits linked with leaf persistence: thicker leaves with high leaf dry mass per area, which is the result of a high amount of non-photosynthetic tissues and a more dense and compact leaf structure (Bieras and Sajo 2009; Hoffmann et al. 2005; Rossatto et al. 2009). This response to soil oligotrophy allows strategies that, in turn, will not only help to reduce the palatability to herbivores (Cooper and Owen-Smith 1986; Wright and Cannon 2001), but it would also favour the species to cope with abiotic filters such as drought (Mediavilla et al. 2001) and high light intensities (Rossatto et al. 2013a) during firefree intervals.

The majority of savanna woody plants are reported to have sclerophyllous leaves, which are thick and rigid, showing a thick waxy cuticle, large amounts of mechanical tissue, palisade parenchyma, and a well-developed vascular system (Goodland 1971; Morretes 1967, 1969; Sarmiento et al. 1985; Fensham and Bowman 1995; Bieras and Sajo 2009 and references therein). This expected and well-reported strategy of scleromorphic leaves in savanna woody species should not be widespread in the ground-layer vegetation, as this layer is composed of small plants that are completely destroyed during the passage of fire, because the aerial parts do not possess the thick bark necessary to survive fire (Hoffmann 1996). As a result, herbaceous plants need to grow fast to achieve a minimum reproductive size before the next fire event (Hoffmann 1996; Hoffmann et al. 2009, 2012). Moreover, most ground-layer plants are either annuals or have underground buds, bulbs, or rhizomes and survive in a dormant leafless state during the drought peri- ods. This strategy reinforces the necessity of short-lived, low-cost mesomorphic leaves with high resource acquisition rates and high leaf productivity to compensate for the relatively short growth period and to facilitate rapid completion of the life cycle (Westoby and Wright 2006).

In South America, the savannas of Brazil, regionally called "Cerrado", is one of the most diverse savannas of the world with respect to vegetation types and plant species (Myers 1990; Gottsberger and Silberbauer-Gottsberger 2006). One hectare of typical Cerrado can hold a diverse plant assemblage (Gottsberger and Silberbauer-Gottsberger 2006), that encompasses various herbaceous (grasses, herbs, subshrubs, and vines) and woody (shrubs, palms, and trees) growth forms (Eiten 1972; Ribeiro and Walter 2008). In terms of proportion, there are three to five times as many plant species in the Cerrado ground-layer vegetation than in the arboreal community (Filgueiras 2002; Gottsberger and Silberbauer-Gottsberger 2006).

Many studies have reported on leaf functional attributes of savanna trees and grasses (Skarpe 1996; Prior et al. 2004; Pausas et al. 2004; Franco et al. 2005). However, studies of leaf anatomy of eudicot herbs focusing on adaptations and functional relationships, as shaped by the most important savanna determinants, are lacking (Tjoelker et al. 2005). In this context, the present paper sheds light on the ecological anatomy of savanna plants at the community level. We characterized qualitative and quantitative aspects of leaf anatomy and the degree of leaf sclerophylly of 57 plant species growing side-by-side, but differing in their growth forms and belonging to distinct families in the angiosperm phylogeny (The Angiosperm Phylogeny Group 2009). This approach was performed to control for phylogenetic influence on leaf anatomy and test for the growth form effect (Felsenstein 1985). We hypothesized that leaf anatomy would diverge among growth forms, as the plant form (Niklas et al. 2007; Santiago and Wright 2007) is related to leaf structure in environments characterised by frequent fire and highly seasonal rainfall (Bond and Keeley 2005). We expected that herbs would show a leaf structure that would facilitate rapid growth after fire events (thinner leaves with low leaf mass per area and low amount of sclerified tissues), while more lignified plants would show leaf anatomy related to persistence between fire intervals (thicker leaves possessing high amounts of sclerified tissues).

\section{Methods}

Study area

We performed our study at the Instituto Brasileiro de Geografia e Estatística (IBGE) Ecological Reserve, a federal reserve located in the southern region of Brasília, DF-Brazil $\left(15^{\circ} 56^{\prime} 40.47^{\prime \prime} \mathrm{S}, 47^{\circ} 52^{\prime} 42.38^{\prime \prime} \mathrm{W}\right)$. The reserve contains different physiognomy types of Neotropical savanna vegetation, but the typical savanna (cerrado sensu stricto) with abundant evergreen and deciduous 
Fig. 1. Phylogenetic relationships among the 57 studied species. Name and authority of the species followed by growth form (T, tree; S, shrub; SS, subshrub; H, herb; G, grass; P, palm; V, vine). Names at intermediate positions indicate strong monophyletic groups according to APG III (The Angiosperm Phylogeny Group 2009).

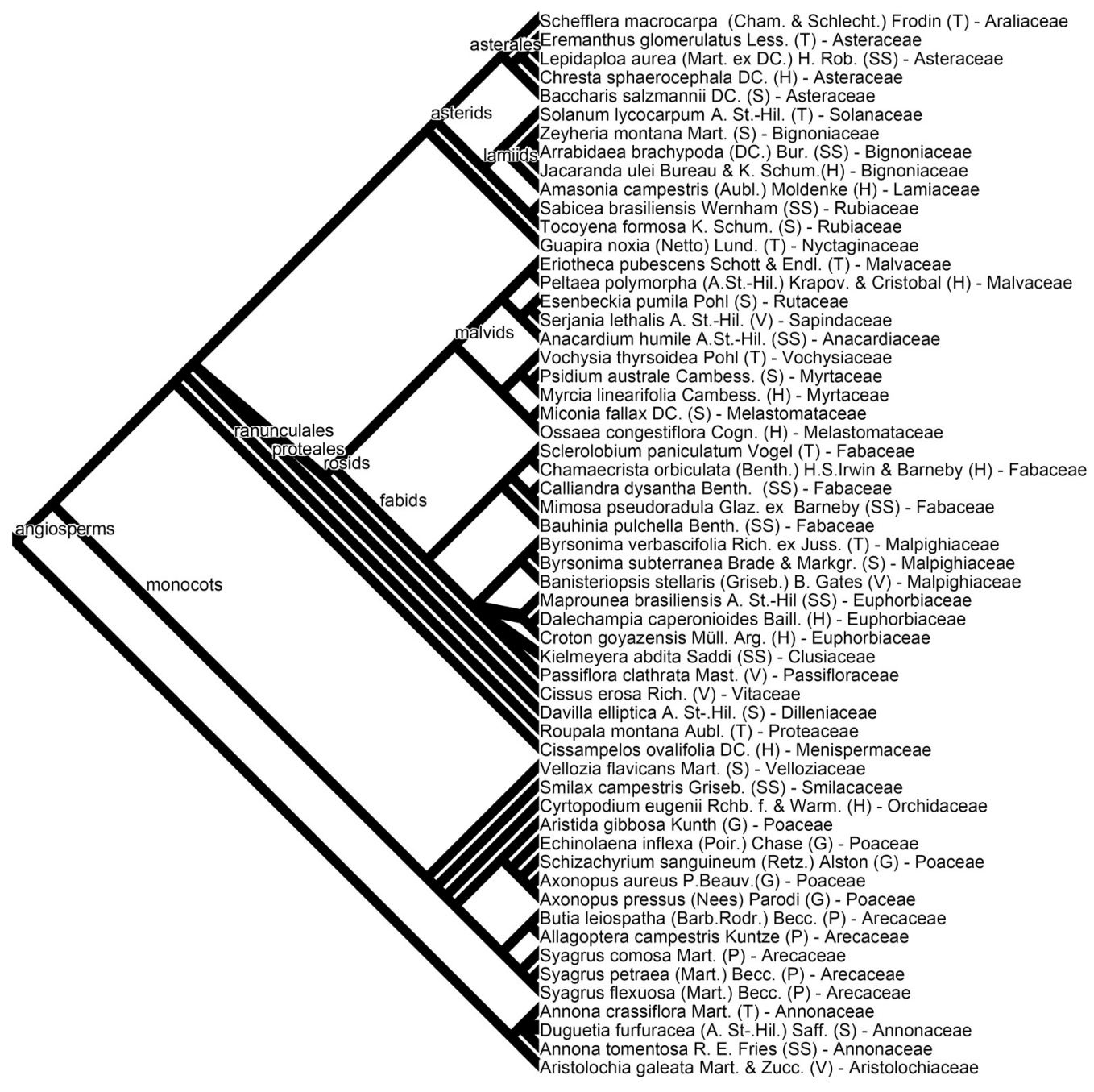

trees and an herbaceous understorey predominates. Our study site was located at a mean elevation of $1100 \mathrm{~m}$ a.s.1., subjected to an annual precipitation of about $1450 \mathrm{~mm}$ (historical mean for 1990-2005) and a pronounced dry season spanning from May to September. In the year of our study (2009), the total rainfall was $1740 \mathrm{~mm}$, with a rainless period extending from mid-June to the last week of August. Mean monthly temperature ranges from 19 to $23{ }^{\circ} \mathrm{C}$, with maximum temperatures achieving $30{ }^{\circ} \mathrm{C}$ in summer and minimum temperatures reaching around $6{ }^{\circ} \mathrm{C}$ in winter. The predominant soils are deep and welldrained oxisols.

\section{Studied species}

We selected species growing in five $20 \mathrm{~m} \times 50 \mathrm{~m}$ plots located at an extended and continuous cerrado sensu stricto physiognomy during February 2009. Soil within these plots was typical dystrophic oxisol with low $\mathrm{pH}$ (5.28), elevated aluminium content $\left(\mathrm{H}^{+} \mathrm{Al}=6.94 \mathrm{cmol} \cdot \mathrm{dm}^{-3}\right)$ and low in macronutrients $\left(\mathrm{P}=0.46 \mathrm{mg} \cdot \mathrm{dm}^{-3} ; \mathrm{Ca}=0.11 \mathrm{cmol} \cdot \mathrm{dm}^{-3}\right.$; $\left.\mathrm{Mg}=0.06 \mathrm{cmol} \cdot \mathrm{dm}^{-3}\right)$. We sampled 57 species from differ- ent families belonging to different growth forms (Fig. 1). The growth form classification was based upon field observations using the criteria presented in Dansereau (1951) and Eiten (1972). The selected forms ranged from herbaceous to lignified growth forms, comprising trees, palms, shrubs, subshrubs, herbs, grasses and vines (climbers). The number of species of each growth form was dependent on their availability in the plot. We sampled 10 species of trees, 10 species of shrubs, 11 species of subshrubs, 11 species of herbs, and 5 species each of grasses, palms, and vines. The selected species represent the most common and dominant species reported for this type of vegetation (Mendonça et al. 2008). We sampled in a way that each of the highest clades (or nodes) of the angiosperm phylogeny (e.g., Campanulids, Lamiids, Fabids, etc.) were represented by at least one tree, one shrub, one subshrub, and one herb (Fig. 1).

\section{Leaf anatomy}

We sampled completely expanded sunlit leaves, without any sign of senescence or herbivory damage, located 
at the second or third node from the tip of branches (woody species), stems (herbs, subshrubs, vines) or culms (grasses). We collected one mid-leaf section (including the main vein) from four individuals (one per individual) of each species. Samples were fixed in formalin - acetic acid - alcohol 70\% (FAA 70), dehydrated in a graded ethanol series, infiltrated and embedded in paraffin, and cut into $8 \mu \mathrm{m}$ sections (Johansen 1940). The cross-sections were stained with astra blue - basic fuchsine (Kraus et al. 1998) and were permanently mounted in Entellan. To detect the presence of ergastic substances, we used the following histochemical tests: ferric ferricyanide (Lison 1960) to show phenolic compounds, $1 \%$ aqueous Alcian Blue 8G to detect mucopolysaccharide (Johansen 1940), hydrochloric acid to detect calcium crystals, and hydrofluoric acid to identify silica bodies (Kraus and Arduin 1997). Paradermic sections were obtained using epidermal prints of dissociated material in 1:1 acetic acid and hydrogen peroxide solution, stained with Safranine O (Kraus and Arduin 1997).

We also qualitatively characterized the following structures: (1) cuticle (thin or thick, in adaxial and abaxial leaf surface); (2) epidermis (composed of one, two, or multiple layers); (3) subepidermal layers (presence of tissue resembling hypodermis); (4) mesophyll organization (homogenous, dorsiventral, or isobilateral); (5) mesophyll ergastic substances (presence or absence of calcium crystals, silica bodies, phenolic compounds and mucilaginous substances); (6) stomata (presence on one or both leaf surfaces); (7) sclerenchyma (localization) and (8) bundle sheath extension (present or absent). All these qualitative descriptions followed well-established references for anatomical studies (Metcalf and Chalk 1979; Evert 2006). We also measured the thickness of the cuticle, thickness of the abaxial and adaxial faces of the epidermis, thickness of the mesophyll, and the total leaf thickness. We took 50 measurements using a $10 \times$ objective lens for each sample. These measurements were taken using the software ImagePro 4.0.

\section{Quantifying leaf scleromorphism}

To quantify the degree of leaf scleromorphism, we measured leaf dry mass per area (LMA; $\mathrm{g} \cdot \mathrm{cm}^{-2}$ ), a measurement widely used to infer this parameter (Read and Sanson 2003). LMA was measured in one leaf per individual, sampling five individuals per species. Leaf area was determined with the software Image (Rasband 19972012) and leaf mass was determined after leaves were oven-dried at $70{ }^{\circ} \mathrm{C}$ for $72 \mathrm{~h}$.

\section{Statistical analysis}

To infer the effect of type of growth form on the thickness of the measured tissues and on the degree of leaf sclerophylly (LMA values), we performed a one-way ANOVA, using growth form as a fixed factor. In this analysis, species of each growth form were used as replicate. The mean value obtained from five individuals per spe- cies was used in the statistical procedure. We also performed a multiple regression to determine the most important anatomical feature (cuticle, epidermis, mesophyll, and total leaf thickness) influencing the values of LMA of the studied growth forms. To verify whether species of distinct growth forms had a similar syndrome of anatomical leaf traits (qualitative and quantitative), we used nonmetric multidimensional scaling (NMDS) analysis (Gotelli and Ellison 2004). All quantitative data were $Z$-standardized before analysis. Because we included quantitative and qualitative data in the NMDS analysis, we used the Gower distance to calculate the distance matrix between the studied leaf anatomical traits. All analyses were performed in the software Past 2.0 (Hammer et al. 2001).

\section{Results}

\section{Leaf anatomy: qualitative aspects}

We found a large variation in leaf anatomy of the studied species (Fig. 2, Table1). One of the most striking aspects that differed among growth forms was the thickness of the cuticle: the cuticle was well developed in trees (Fig. 2I), while it was not as prominent in grasses and herbs (Fig. 2A and 2B, respectively).

The epidermis of most species was composed of a single layer of cells independent of growth form (Fig. 2A$2 \mathrm{G}$, Table 1). Biseriate or triseriate epidermis was not common. There was a great diversity of cell shapes (Fig. 2), without a clear pattern among growth forms. The most common cell types were prismatic, columnar, and cylindrical. Hypodermis was found in all palms (Table 1) and in a few other species (Fig. 2H-2I).

All grasses and palms had homogenous mesophyll (Fig. 2A and 2F, Table 1). This type of organization of the mesophyll was also found for the subshrubs Bauhinia pulchella Benth. and Smilax campestris Griseb. and the herb Cyrtopodium eugenii Rchb.f. \& Warm. (Table 1). All other species had dorsiventral mesophyll. In general, the palisade and spongy parenchymas were well defined in eudicotyledons (Fig. 2). Palisade parenchyma was characterized by rectangular cells, ranging from 1 to 5-6 cell layers thick (Fig. 2). Spongy parenchyma in turn was very variable in terms of cell layers, with a range from 3 to 11 layers, being more or less compacted according to the species (Fig. 2).

In relation to ergastic substances, we found phenolic compounds (Figs. 2D, 2F, 2G) and mucilage (Table 1), with the latter located specifically in the epidermal cells. Calcium crystals were found in several species (Table 1), while silica bodies were found in all grasses, in palm species from genus Syagrus, and in one herb (Table 1).

Sclerified cells were abundant in the studied species (Table 1). Sclerified cells were frequently found in leaves of trees, shrubs, grasses, and palms, especially in the bundle sheath extension (Fig. 2D and 2H, Table 1). In contrast, the majority of herbs and vines had a smaller amount of sclerified cells in their leaves, which were mainly associated with the vascular bundles (Table 1). 
Fig. 2. Structural diversity of leaf cross sections of the studied growth forms. (A) Echinolaena inflexa (grass); (B) Amasonia campestris (herb); (C) Cyrtopodium eugenii (herb); (D) Bauhinia pulchella (subshrub); (E) Aristolochia galeata (vine); (F) Syagrus flexuosa (palm); (G) Tocoyena formosa (shrub); (H) Vochysia thyrsoidea (tree); and (I) Schefflera macrocarpa (tree). Abe, abaxial face of epidermis; Ade, adaxial face of epidermis; Bc, bulliform cell; Cu, cuticle; Hy, hypodermis; PP, palisade parenchyma; SP, spongy parenchyma; Tt, tector trichome; BSE, bundle sheath extension; Hm, homogenous mesophyll; Phe, phenolic compounds; $\mathrm{S}$, stomata. Arrow in Fig. 2E indicates secretory channel. Arrow in Fig. $2 \mathrm{G}$ indicates calcium crystal. Scale bars $=100 \mu \mathrm{m}$. (This figure is available in colour online.)
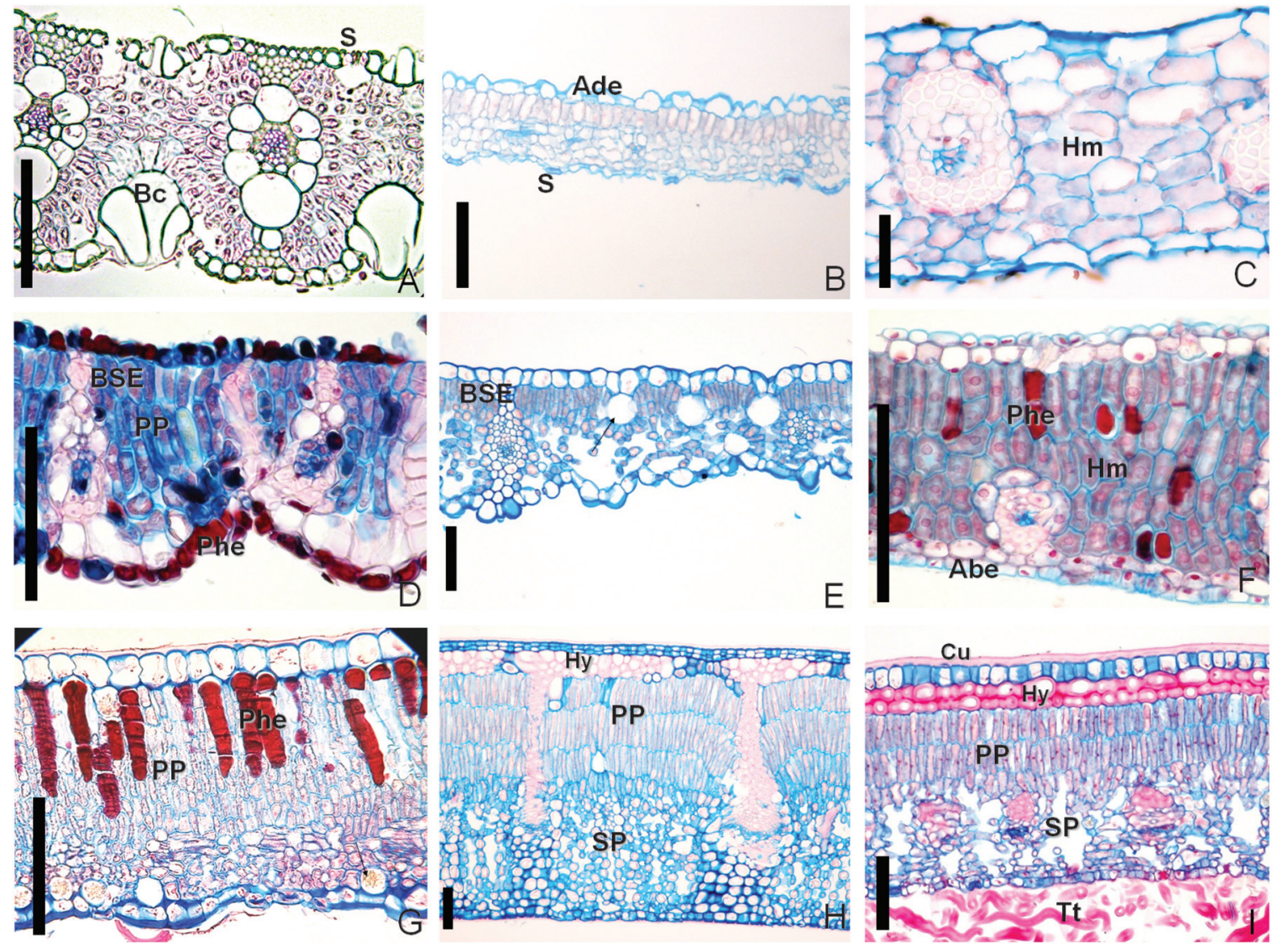

Stomata were present on both leaf surfaces in 21 of the 57 species. They were restricted to the abaxial leaf surface in all remaining species (Table 1). The presence of stomata was not always linked with the presence of trichomes (Table 1). The majority of trichomes were of the tector type and not all species had them (Table 1).

\section{Leaf anatomy: quantitative aspects}

We found a great variation in thickness of the different leaf tissues among growth forms (Fig. 3). We found significant differences $\left(\mathrm{F}_{[6,50]}=4.12, \mathrm{P}<0.01\right)$ for cuticle thickness (Fig. 3A); in thickness of the adaxial face of the epidermis $\left(\mathrm{F}_{[6,50]}=3.50, \mathrm{P}<0.01\right.$, Fig. $\left.3 \mathrm{D}\right)$; and also in the thickness of the abaxial face of the epidermis $\left(\mathrm{F}_{[6,50]}=\right.$ 3.62, $P<0.01$, Fig. 3E). Mesophyll thickness (Fig. 3B; $\left.\mathrm{F}_{[6,50]}=4.92, P<0.01\right)$ and total leaf thickness $\left(\mathrm{F}_{[6,50]}=4.19\right.$, $P<0.01$; Fig. 3C) differed among growth forms. There were also differences on the ratio of mesophyll to leaf thickness $\left(\mathrm{F}_{[6,50]}=2.42, \mathrm{P}=0.03\right)$. Grasses had the lowest ratio (Fig. $3 F$ ). Trees had the highest values of thickness for most tissues, while grasses had the lowest values (Fig. 3), with the exception of the thickness of the adaxial face of epidermis (Fig. 3D). Herbs had the lowest values of thickness for this particular tissue.

\section{Leaf sclerophylly}

The growth forms differed in the degree of leaf sclerophylly $\left(\mathrm{F}_{[6,50]}=6.04, P<0.01\right)$. The most scleromorphic (highest values of LMA) growth forms were trees, shrubs, and palms, while grasses and herbs had the lowest LMA; subshrubs and vines showed intermediate values (Fig. 4A). Total leaf thickness was the only significant surrogate anatomical trait $(\beta=0.5022, P=0.048)$ to correlate with variations in LMA (Fig. $4 \mathrm{~B}$ ), independently of the type of growth form. Cuticle $(\beta=0.200, P=0.056)$, epidermis $(\beta=0.098, P=0.5041)$, and mesophyll thickness $(\beta=0.058, P=0.89)$ did not correlate with variations in LMA.

\section{Leaf anatomical syndrome and ordination of species}

The NMDS analysis was robust. The determination coefficient was 0.967 and the stress value was low (0.135). The NMDS analysis segregated the species into four welldefined groups: woody species (trees, shrubs, and 2 out of 
Table 1. Description of characters from the anatomical sections of leaves of different growth forms co-existing in an area of cerrado sensu stricto.

\begin{tabular}{|c|c|c|c|c|c|c|c|c|c|c|}
\hline $\begin{array}{l}\text { Growth form } \\
\text { and species }\end{array}$ & Family & $\begin{array}{l}\text { Prominent } \\
\text { cuticle }\end{array}$ & Epi & Hy & Mesophyll & $\begin{array}{l}\text { Ergastic } \\
\text { substances }\end{array}$ & Trichomes & Stomata & Scle & Bse \\
\hline \multicolumn{11}{|l|}{ Trees } \\
\hline Schefflera macrocarpa & Araliaceae & $\mathrm{AD}, \mathrm{AB}$ & $\mathrm{U}$ & $\mathrm{P}$ & $\mathrm{D}$ & $\mathrm{Cr}$ & $\mathrm{AB}$ & $\mathrm{AB}$ & $\mathrm{Hy}, \mathrm{Vb}$ & - \\
\hline Eremanthus glomerulatus & Asteraceae & $\mathrm{AD}$ & $\mathrm{U}$ & - & $\mathrm{D}$ & - & $\mathrm{AD}, \mathrm{AB}$ & $\mathrm{AB}$ & - & Pare \\
\hline Solanum lycocarpum & Solanaceae & $\mathrm{AD}$ & $\mathrm{U}$ & - & $\mathrm{D}$ & $\mathrm{Cr}$ & $\mathrm{AD}, \mathrm{AB}$ & $\mathrm{AD}, \mathrm{AB}$ & - & Pare \\
\hline Eriotheca pubescens & Malvaceae & $\mathrm{AD}, \mathrm{AB}$ & $\mathrm{U}$ & $\mathrm{P}$ & $\mathrm{D}$ & $\mathrm{Ph}, \mathrm{Mu}, \mathrm{Cr}$ & $\mathrm{AD}, \mathrm{AB}$ & $\mathrm{AB}$ & Bse, Hy & Scle \\
\hline Sclerolobium paniculatum & Fabaceae & $\mathrm{AD}, \mathrm{AB}$ & $\mathrm{U}$ & - & $\mathrm{D}$ & $\mathrm{Ph}, \mathrm{Cr}$ & $\mathrm{AD}, \mathrm{AB}$ & $\mathrm{AB}$ & Bse & Scle \\
\hline Byrsonima verbascifolia & Malpighiaceae & $\mathrm{AD}$ & $\mathrm{U}$ to $\mathrm{B}$ & - & $\mathrm{D}$ & $\mathrm{Ph}, \mathrm{Mu}, \mathrm{Cr}$ & $\mathrm{AD}, \mathrm{AB}$ & $\mathrm{AB}$ & Bse & Scle \\
\hline Vochysia thyrsoidea & Vochysiaceae & $\mathrm{AD}, \mathrm{AB}$ & B & $\mathrm{P}$ & $\mathrm{D}$ & $\mathrm{Ph}, \mathrm{Cr}$ & - & $\mathrm{AB}$ & Bse & Pare, Scle \\
\hline Roupala montana & Proteaceae & $\mathrm{AD}, \mathrm{AB}$ & $\mathrm{U}$ & - & $\mathrm{D}$ & $\mathrm{Ph}$ & $\mathrm{AD}, \mathrm{AB}$ & $\mathrm{AB}$ & Mes, Vb & - \\
\hline Guapira noxia & Nyctaginaceae & $\mathrm{AD}, \mathrm{AB}$ & $\mathrm{U}$ & - & $\mathrm{D}$ & - & $\mathrm{AD}, \mathrm{AB}$ & $\mathrm{AB}$ & Bse & Pare, Scle \\
\hline Annona crassiflora & Annonaceae & $\mathrm{AD}$ & $\mathrm{B}$ to $\mathrm{T}$ & - & $\mathrm{D}$ & $\mathrm{Ph}, \mathrm{Mu}$ & $\mathrm{AD}, \mathrm{AB}$ & $\mathrm{AB}$ & Bse & Pare, Scle \\
\hline \multicolumn{11}{|l|}{ Shrubs } \\
\hline Baccharis salzmannii & Asteraceae & - & $\mathrm{U}$ & - & $\mathrm{D}$ & - & $\mathrm{AD}, \mathrm{AB}$ & $\mathrm{AB}$ & $\mathrm{Vb}$ & - \\
\hline Zeyheria montana & Bignoniaceae & $\mathrm{AD}, \mathrm{AB}$ & $\mathrm{U}$ & - & $\mathrm{D}$ & - & $\mathrm{AB}$ & $\mathrm{AB}$ & Bse & Pare, Scle \\
\hline Tocoyena formosa & Rubiaceae & $\mathrm{AD}$ & $\mathrm{U}$ & - & $\mathrm{D}$ & $\mathrm{Ph}, \mathrm{Cr}$ & $\mathrm{AD}, \mathrm{AB}$ & $\mathrm{AB}$ & - & - \\
\hline Esenbeckia pumila & Rutaceae & $\mathrm{AD}$ & $\mathrm{U}$ to $\mathrm{B}$ & - & $\mathrm{D}$ & $\mathrm{Ph}, \mathrm{Cr}$ & $\mathrm{AD}, \mathrm{AB}$ & $\mathrm{AB}$ & Bse & Pare, Scle \\
\hline Byrsonima subterranea & Malpighiaceae & $\mathrm{AD}$ & $\mathrm{U}$ to $\mathrm{B}$ & - & $\mathrm{D}$ & $\mathrm{Ph}, \mathrm{Mu}, \mathrm{Cr}$ & $\mathrm{AD}, \mathrm{AB}$ & $\mathrm{AB}$ & $\mathrm{Vb}$, Bse & Pare, Scle \\
\hline Miconia fallax & Melastomataceae & $\mathrm{AD}$ & $\mathrm{U}$ & - & $\mathrm{D}$ & $\mathrm{Ph}, \mathrm{Cr}$ & $\mathrm{AB}$ & $\mathrm{AB}$ & - & - \\
\hline Psidium australe & Myrtaceae & $\mathrm{AD}, \mathrm{AB}$ & $\mathrm{U}$ & $\mathrm{P}$ & $\mathrm{D}$ & $\mathrm{Ph}, \mathrm{Cr}$ & $\mathrm{AD}, \mathrm{AB}$ & $\mathrm{AD}, \mathrm{AB}$ & $\mathrm{Vb}$ & - \\
\hline Davilla elliptica & Dilleniaceae & $\mathrm{AD}$ & $\mathrm{U}$ & - & $\mathrm{D}$ & $\mathrm{Cr}, \mathrm{Ph}, \mathrm{Mu}$ & $\mathrm{AD}, \mathrm{AB}$ & $\mathrm{AB}$ & - & - \\
\hline Vellozia flavicans & Velloziaceae & $\mathrm{AD}, \mathrm{AB}$ & $\mathrm{U}$ & $\mathrm{P}$ & $\mathrm{D}$ & - & $\mathrm{AB}$ & $\mathrm{AD}, \mathrm{AB}$ & Bse, Mes & Scle \\
\hline Duguetia furfuracea & Annonaceae & $\mathrm{AD}$ & $\mathrm{U}$ to $\mathrm{B}$ & - & $\mathrm{D}$ & $\mathrm{Ph}, \mathrm{Cr}, \mathrm{Mu}$ & $\mathrm{AB}, \mathrm{AD}$ & $\mathrm{AB}$ & Bse & Scle \\
\hline \multicolumn{11}{|l|}{ Subshrubs } \\
\hline Calliandra dysantha & Fabaceae & $\mathrm{AD}$ & $\mathrm{U}$ & - & $\mathrm{D}$ & $\mathrm{Ph}$ & $\mathrm{AD}, \mathrm{AB}$ & $\mathrm{AB}$ & - & - \\
\hline Lepidaploa aurea & Asteraceae & - & $\mathrm{U}$ & - & $\mathrm{D}$ & $\mathrm{Cr}$ & $\mathrm{AD}, \mathrm{AB}$ & $\mathrm{AB}$ & Bse & Pare, Scle \\
\hline Sabicea brasiliensis & Rubiaceae & $\mathrm{AD}$ & $\mathrm{U}$ to $\mathrm{B}$ & - & $\mathrm{D}$ & $\mathrm{Ph}, \mathrm{Cr}$ & $\mathrm{AD}, \mathrm{AB}$ & $\mathrm{AB}$ & - & Pare \\
\hline Arrabidaea brachypoda & Bignoniaceae & - & $\mathrm{U}$ & - & $\mathrm{D}$ & $\mathrm{Cr}$ & $\mathrm{AD}, \mathrm{AB}$ & $\mathrm{AB}$ & Bse & Scle \\
\hline Anacardium humile & Anacardiaceae & $\mathrm{AD}, \mathrm{AB}$ & $\mathrm{U}$ & - & $\mathrm{D}$ & $\mathrm{Ph}, \mathrm{Cr}$ & $\mathrm{AD}, \mathrm{AB}$ & $\mathrm{AD}, \mathrm{AB}$ & Bse, Epi & Scle \\
\hline Maprounea brasiliensis & Euphorbiaceae & $\mathrm{AD}, \mathrm{AB}$ & $\mathrm{U}$ & - & $\mathrm{D}$ & $\mathrm{Ph}$ & - & $\mathrm{AB}$ & Bse & Scle \\
\hline Mimosa pseudoradula & Fabaceae & $\mathrm{AD}, \mathrm{AB}$ & $\mathrm{U}$ & - & $\mathrm{D}$ & $\mathrm{Ph}$ & $\mathrm{AB}$ & $\mathrm{AD}, \mathrm{AB}$ & Vb, Mes & - \\
\hline Bauhinia pulchella & Fabaceae & - & $\mathrm{U}$ & - & $\mathrm{H}$ & $\mathrm{Ph}, \mathrm{Mu}, \mathrm{Cr}$ & $\mathrm{AD}, \mathrm{AB}$ & $\mathrm{AD}, \mathrm{AB}$ & Bse & Scle \\
\hline Kielmeyera abdita & Clusiaceae & $\mathrm{AD}, \mathrm{AB}$ & $\mathrm{U}$ & - & $\mathrm{D}$ & $\mathrm{Ph}, \mathrm{Cr}$ & - & $\mathrm{AB}$ & Bse & Scle \\
\hline Smilax campestris & Smilacaceae & $\mathrm{AD}, \mathrm{AB}$ & $\mathrm{U}$ & - & $\mathrm{H}$ & $\mathrm{Ph}$ & - & $\mathrm{AD}, \mathrm{AB}$ & $\mathrm{Vb}$ & - \\
\hline Annona tomentosa & Annonaceae & $\mathrm{AD}$ & $\mathrm{B}$ to $\mathrm{T}$ & - & $\mathrm{D}$ & $\mathrm{Mu}, \mathrm{Ph}$ & $\mathrm{AD}, \mathrm{AB}$ & $\mathrm{AB}$ & Bse & Scle \\
\hline \multicolumn{11}{|l|}{ Herbs } \\
\hline Chresta sphaerocephala & Asteraceae & - & $\mathrm{U}$ & - & $\mathrm{D}$ & - & $\mathrm{AD}, \mathrm{AB}$ & $\mathrm{AD}, \mathrm{AB}$ & Bse & Scle \\
\hline Amasonia campestris & Lamiaceae & - & $\mathrm{U}$ & - & $\mathrm{D}$ & - & $\mathrm{AD}, \mathrm{AB}$ & $\mathrm{AD}, \mathrm{AB}$ & - & - \\
\hline Jacaranda ulei & Bignoniaceae & $\mathrm{AD}$ & $\mathrm{U}$ & - & $\mathrm{D}$ & $\mathrm{Ph}$ & $\mathrm{AD}, \mathrm{AB}$ & $\mathrm{AB}$ & - & - \\
\hline Ossaea congestiflora & Melastomataceae & - & $\mathrm{U}$ & - & $\mathrm{D}$ & $\mathrm{Cr}$ & $\mathrm{AB}$ & $\mathrm{AB}$ & - & - \\
\hline
\end{tabular}


Table 1 (concluded).

\begin{tabular}{|c|c|c|c|c|c|c|c|c|c|c|}
\hline $\begin{array}{l}\text { Growth form } \\
\text { and species }\end{array}$ & Family & $\begin{array}{l}\text { Prominent } \\
\text { cuticle }\end{array}$ & Epi & Hy & Mesophyll & $\begin{array}{l}\text { Ergastic } \\
\text { substances }\end{array}$ & Trichomes & Stomata & Scle & Bse \\
\hline Peltaea polymorpha & Malvaceae & - & $\mathrm{U}$ & - & $\mathrm{D}$ & $\mathrm{Ph}, \mathrm{Mu}, \mathrm{Cr}$ & $\mathrm{AD}, \mathrm{AB}$ & $\mathrm{AD}, \mathrm{AB}$ & $\mathrm{Vb}$ & - \\
\hline Chamaecrista orbiculata & Fabaceae & $\mathrm{AD}, \mathrm{AB}$ & $\mathrm{U}$ & - & $\mathrm{D}$ & - & - & $\mathrm{AD}, \mathrm{AB}$ & $\mathrm{Vb}$ & - \\
\hline Myrcia linearifolia & Myrtaceae & $\mathrm{AD}, \mathrm{AB}$ & $\mathrm{U}$ & 一 & $\mathrm{D}$ & $\mathrm{Ph}, \mathrm{Cr}$ & $\mathrm{AD}, \mathrm{AB}$ & $\mathrm{AB}$ & Bse & Scle \\
\hline Croton goyazensis & Euphorbiaceae & $\mathrm{AD}$ & $\mathrm{U}$ & - & $\mathrm{D}$ & $\mathrm{Ph}$ & $\mathrm{AD}, \mathrm{AB}$ & $\mathrm{AD}, \mathrm{AB}$ & $\mathrm{Vb}$ & - \\
\hline $\begin{array}{l}\text { Dalechampia } \\
\text { caperonioides }\end{array}$ & Euphorbiaceae & $\mathrm{AD}, \mathrm{AB}$ & $\mathrm{U}$ & - & $\mathrm{D}$ & $\mathrm{Cr}$ & $\mathrm{AD}, \mathrm{AB}$ & $\mathrm{AD}, \mathrm{AB}$ & $\mathrm{Vb}$ & - \\
\hline Cissampelos ovalifolia & Menispermaceae & $\mathrm{AD}$ & $\mathrm{U}$ & - & $\mathrm{D}$ & - & $\mathrm{AD}, \mathrm{AB}$ & $\mathrm{AB}$ & Bse & Scle \\
\hline Cyrtopodium eugenii & Orchidaceae & - & $\mathrm{U}$ & 一 & $\mathrm{H}$ & $\mathrm{Sb}$ & - & $\mathrm{AB}$ & $\mathrm{Vb}$ & - \\
\hline \multicolumn{11}{|l|}{ Grasses } \\
\hline Axonopus pressus & Poaceae & - & $\mathrm{U}$ & - & $\mathrm{H}$ & $\mathrm{Sb}$ & - & $\mathrm{AB}$ & Bse & Scle \\
\hline Aristida gibbosa & Poaceae & - & $\mathrm{U}$ & - & $\mathrm{H}$ & $\mathrm{Sb}$ & $\mathrm{AD}, \mathrm{AB}$ & $\mathrm{AD}, \mathrm{AB}$ & Bse & Scle \\
\hline Axonopus aureus & Poaceae & 一 & $\mathrm{U}$ & - & $\mathrm{H}$ & $\mathrm{Sb}$ & $\mathrm{AD}, \mathrm{AB}$ & $\mathrm{AD}, \mathrm{AB}$ & Bse & Scle \\
\hline Echinolaena inflexa & Poaceae & - & $\mathrm{U}$ & 一 & $\mathrm{H}$ & $\mathrm{Sb}$ & $\mathrm{AD}, \mathrm{AB}$ & $\mathrm{AD}, \mathrm{AB}$ & Bse & Scle \\
\hline $\begin{array}{l}\text { Schizachyrium } \\
\text { sanguineum }\end{array}$ & Poaceae & - & $\mathrm{U}$ & - & $\mathrm{H}$ & $\mathrm{Ph}, \mathrm{Sb}$ & $\mathrm{AD}, \mathrm{AB}$ & $\mathrm{AB}$ & Bse & Scle \\
\hline \multicolumn{11}{|l|}{ Palms } \\
\hline Allagoptera campestris & Arecaceae & $\mathrm{AD}, \mathrm{AB}$ & $\mathrm{U}$ & $\mathrm{P}$ & $\mathrm{H}$ & $\mathrm{Ph}$ & - & $\mathrm{AB}$ & Hy, Bse & Scle \\
\hline Butia leiospatha & Arecaceae & $\mathrm{AD}, \mathrm{AB}$ & $\mathrm{U}$ & $\mathrm{P}$ & $\mathrm{H}$ & $\mathrm{Ph}$ & $\mathrm{AD}$ & $\mathrm{AD}, \mathrm{AB}$ & Hy, Bse & Scle \\
\hline Syagrus comosa & Arecaceae & $\mathrm{AD}, \mathrm{AB}$ & $\mathrm{U}$ & $\mathrm{P}$ & $\mathrm{H}$ & $\mathrm{Ph}, \mathrm{Sb}$ & $\mathrm{AD}, \mathrm{AB}$ & $\mathrm{AD}, \mathrm{AB}$ & Hy, Bse & Scle \\
\hline Syagrus flexuosa & Arecaceae & $\mathrm{AD}$ & $\mathrm{U}$ & $\mathrm{P}$ & $\mathrm{H}$ & $\mathrm{Ph}, \mathrm{Sb}$ & $\mathrm{AB}$ & $\mathrm{AD}, \mathrm{AB}$ & Hy, Bse & Scle \\
\hline Syagrus petraea & Arecaceae & $\mathrm{AD}, \mathrm{AB}$ & $\mathrm{U}$ & $\mathrm{P}$ & $\mathrm{H}$ & $\mathrm{Ph}, \mathrm{Sb}$ & - & $\mathrm{AD}, \mathrm{AB}$ & Hy, Bse & Scle \\
\hline \multicolumn{11}{|l|}{ Vines } \\
\hline Cissus erosa & Vitaceae & - & $\mathrm{U}$ & - & $\mathrm{D}$ & $\mathrm{Mu}, \mathrm{Cr}$ & $\mathrm{AD}, \mathrm{AB}$ & $\mathrm{AB}$ & $\mathrm{Vb}$ & - \\
\hline Banisteriopsis stellaris & Malpighiaceae & $\mathrm{AD}$ & $\mathrm{U}$ to $\mathrm{B}$ & 一 & $\mathrm{D}$ & $\mathrm{Ph}, \mathrm{Mu}, \mathrm{Cr}$ & - & $\mathrm{AB}$ & Bse & Scle \\
\hline Serjania lethalis & Sapindaceae & $\mathrm{AD}, \mathrm{AB}$ & $\mathrm{U}$ & - & $\mathrm{D}$ & $\mathrm{Ph}, \mathrm{Mu}$ & $\mathrm{AD}, \mathrm{AB}$ & $\mathrm{AD}, \mathrm{AB}$ & $\mathrm{Vb}$ & - \\
\hline Aristolochia galeata & Aristolochiaceae & - & $\mathrm{U}$ & - & $\mathrm{D}$ & $\mathrm{Mu}$ & $\mathrm{AD}$ & $\mathrm{AB}$ & - & Pare \\
\hline Passiflora clathrata & Passifloraceae & $\mathrm{AD}$ & $\mathrm{U}$ & 一 & $\mathrm{D}$ & $\mathrm{Ph}, \mathrm{Mu}$ & - & $\mathrm{AB}$ & $\mathrm{Vb}$ & - \\
\hline
\end{tabular}

Note: $\mathrm{AB}$, abaxial face of epidermis; $\mathrm{AD}$, adaxial face of epidermis; $\mathrm{B}$, biseriate; $\mathrm{Bse}$, bundle sheath extension; Cr, calcium crystals; Epi, epidermis; $\mathrm{D}$, dorsiventral; $\mathrm{H}$, homogeneous;

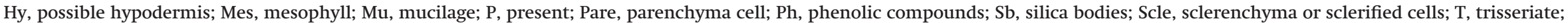
$\mathrm{U}$, uniseriate; $\mathrm{Vb}$, vascular bundle; - , absence of the characteristic. 
Fig. 3. Thickness of the different leaf tissues in distinct growth forms in a Neotropical savanna. (A) Cuticle thickness; (B) mesophyll thickness; (C) total leaf thickness; (D) thickness of adaxial face leaf epidermis; (E) thickness of abaxial face leaf epidermis; and (F) mesophyll/leaf thickness ratio (M/LT). Same letters indicate statistical similarity among growth forms according to Fisher's least significant difference test $(\alpha=0.05)$. Vertical bars indicate SE $(n=5-11$ species).
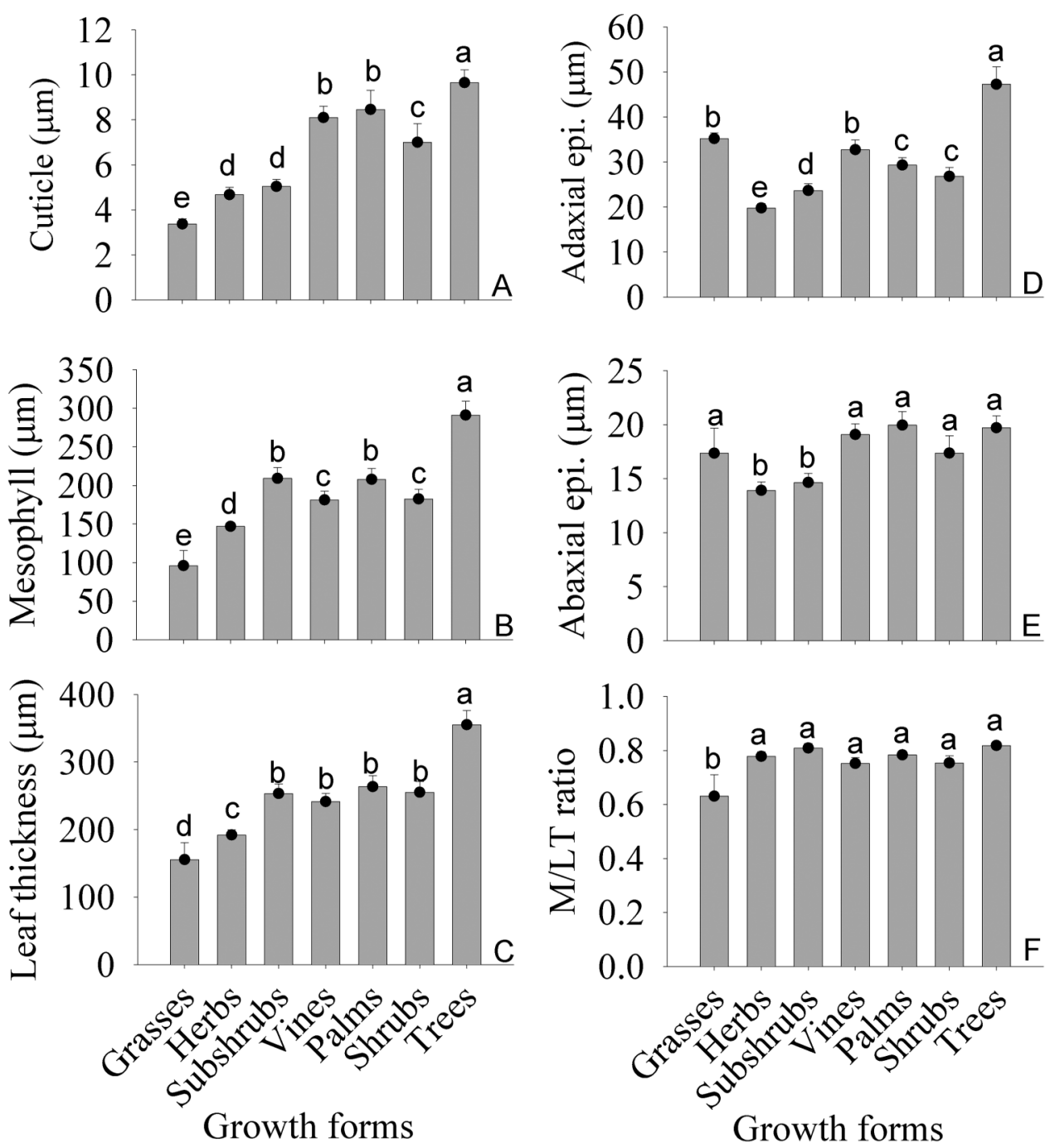

10 subshrubs), herbaceous species (herbs, vines, and all other subshrubs), palms, and grasses (Fig. 5).

\section{Discussion}

We were able to corroborate our hypothesis that leaf anatomy would differ among growth forms. The NMDS analysis clearly segregated the studied community into four groups: herbaceous plants, woody plants, grasses, and palms. Herbaceous growth forms (herbs, vines, grasses, and most subshrubs) were located on the right side of the first axis, while woody plants (trees, shrubs, palms, and two subshrubs) were clustered on the left side. We found a clear separation between palms and the other woody plants and between grasses and the other herbaceous growth forms along the second axis, suggesting a phylogenetic effect on the separation of Arecaceae and Poaceae (all monocots) from the other taxa (all eudicots).

Our data on leaf structure of trees and shrubs are consistent with those reported for savanna woody species in other studies: scleromorphic dorsiventral hypostomatic leaves, with well-developed cuticle, and the presence of a sclerified bundle sheath extension in most species (Bieras and Sajo 2009). In contrast, herbaceous plants tend to have thinner leaves, less developed cuticle, and fewer sclerified cells, which provided significant lower values of LMA in comparison with woody plants, and therefore in their degree of sclerophylly. While most herbaceous plants also had dorsiventral type of mesophyll, grasses and palms showed homogenous mesophyll, the presence of silica bodies, and sclerenchymatous bundle sheath extensions, all common traits related to monocot species (Metcalf and Chalk 1979). Palms differed from grasses by their thicker leaves and the presence of a sclerenchymatous hypodermis. 
Fig. 4. Values of leaf mass per area (LMA) of the studied growth forms (A) and the relationship between leaf thickness and LMA for the set of studied species (B). In Fig. 4A vertical bars indicate standard error of the mean $(n=5-11)$ and same letters indicate similarity according to Fisher's least significant difference test $(\alpha=0.05)$. In Fig. $4 \mathrm{~B}$, each data point represents one species. $\mathrm{G}$, grasses; $\mathrm{H}$, herbs; $\mathrm{SS}$, subshrubs; $V$, vines; $P$, palms; $S B$, shrubs;

$\mathrm{T}$, trees.
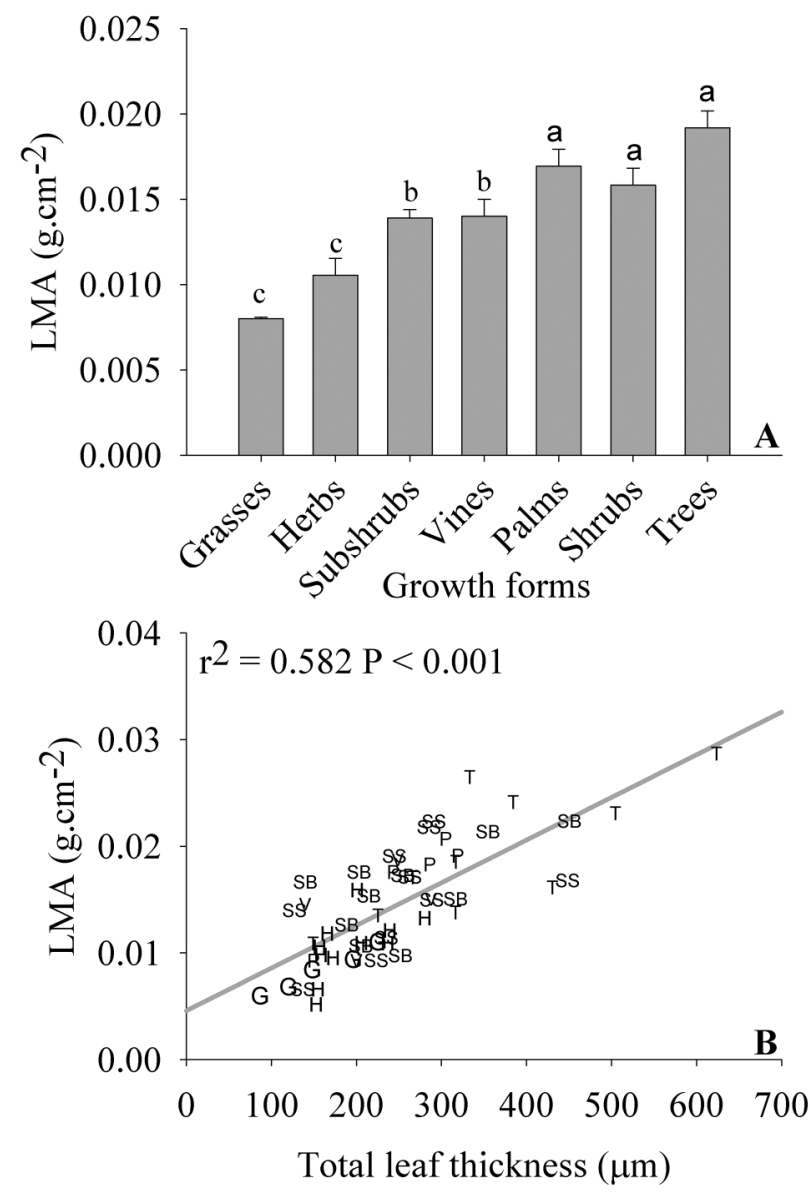

The presence of a prominent cuticle in woody plants may be an anatomical adaptation to protect against the high irradiances that prevail in tropical savannas (Franco and Lüttge 2002; Franco et al. 2007; Tomlinson et al. 2013). Thick cuticles would offer protection not only against high light intensities but also against UV (Vogelmann 1993, Krauss et al. 1997). Additionally, it may favour the leaf water balance, because the cuticle significantly restricts water vapour loss (Pallardy 1981; Fahn and Cutler 1992; Hauke and Schreiber 1998; Riederer and Schreiber 2001). In contrast, leaves of herbaceous species with less developed cuticles should be more prone to leaf desiccation (Riederer and Schreiber 2001). However, most of them are dormant during the dry period, and therefore, less subjected to selection pressures for restricting leaf water loss.

The extension of the bundle sheath, which connects the vascular bundles to the epidermis, was also reported as a characteristic of plants that thrive in highly seasonal environments (Fahn and Cutler 1992), as it can facilitate water transport from the vascular bundles to the epidermis (Evert 2006). There were also suggestions that this structure would provide mechanical support to leaves (Fahn and Cutler 1992; Evert 2006), especially in grasses, which normally have longer leaf blades. Trees and shrubs showed high frequency of species with bundle sheath extensions, sclerenchyma, and thick cuticle, a syndrome of traits that was less frequent in herbs and vines. Hypodermis was present in a few woody species, absent in herbs and subshrubs, and was present in all palms. Arecaceae species usually have leaves with this structure, which is also commonly reported for some genera of Araliaceae and Vochysiaceae (Metcalf and Chalk 1979).

All growth forms had a substantial amount of mesophyll tissue (as a percentage of total leaf thickness), with the exception of grasses. Despite similar mesophyll to leaf thickness ratios among the majority of growth forms, the mesophyll of trees was generally thicker in comparison with other growth forms. This high investment in parenchyma is believed to be a response to exposure to high light intensities (Vogelmann 1993; Larcher 2003; Sefton et al. 2002; Gratani et al. 2006; Rossatto and Kolb 2010), which could directly affect the leaf photosynthetic capacity (Björkman 1981; Paiva et al. 2003). Therefore, the occurrence of a well-developed photosynthetic parenchyma, with biochemical and morphological adaptations to cope with elevated irradiances (Franco and Lüttge 2002; Franco et al. 2007; Tomlinson et al. 2013), suggest that savanna trees would likely have higher values of maximum photosynthesis on a leaf area basis than subshrubs and herbs. In a tropical forest, Santiago and Wright (2007) showed this was the case, when comparing trees and understorey herbs. However, the predominance of $\mathrm{C}_{4}$ grasses in savannas suggests that despite their thin mesophyll, grasses should have higher photosynthetic rates per unit leaf area in comparison with the other growth forms (Anten et al. 1998). Integrative studies of leaf photosynthetic traits and leaf anatomy in Cerrado plants, especially from the herbaceous component, are needed to provide a better understanding of the photosynthetic strategies of the different growth forms.

The total leaf thickness was closely related to the degree of scleromorphism, as evaluated by changes in LMA. There was a strong and positive relationship between leaf thickness and LMA, and a single axis of variation encompassed all growth forms. Trees and grasses were at the opposite ends of this spectrum, with the other growth forms appearing between them. This result suggests that leaf scleromorphism in the studied savanna plants is the result of the high level of investment in tissue thickness in concert with the high frequency of suberized and lignified structures (e.g., extension of the bundle sheath and the presence of sclerenchyma) (Grime 
Fig. 5. Ordination (nonmetric multidimensional scaling) of the distinct growth forms using qualitative and quantitative leaf anatomical data.

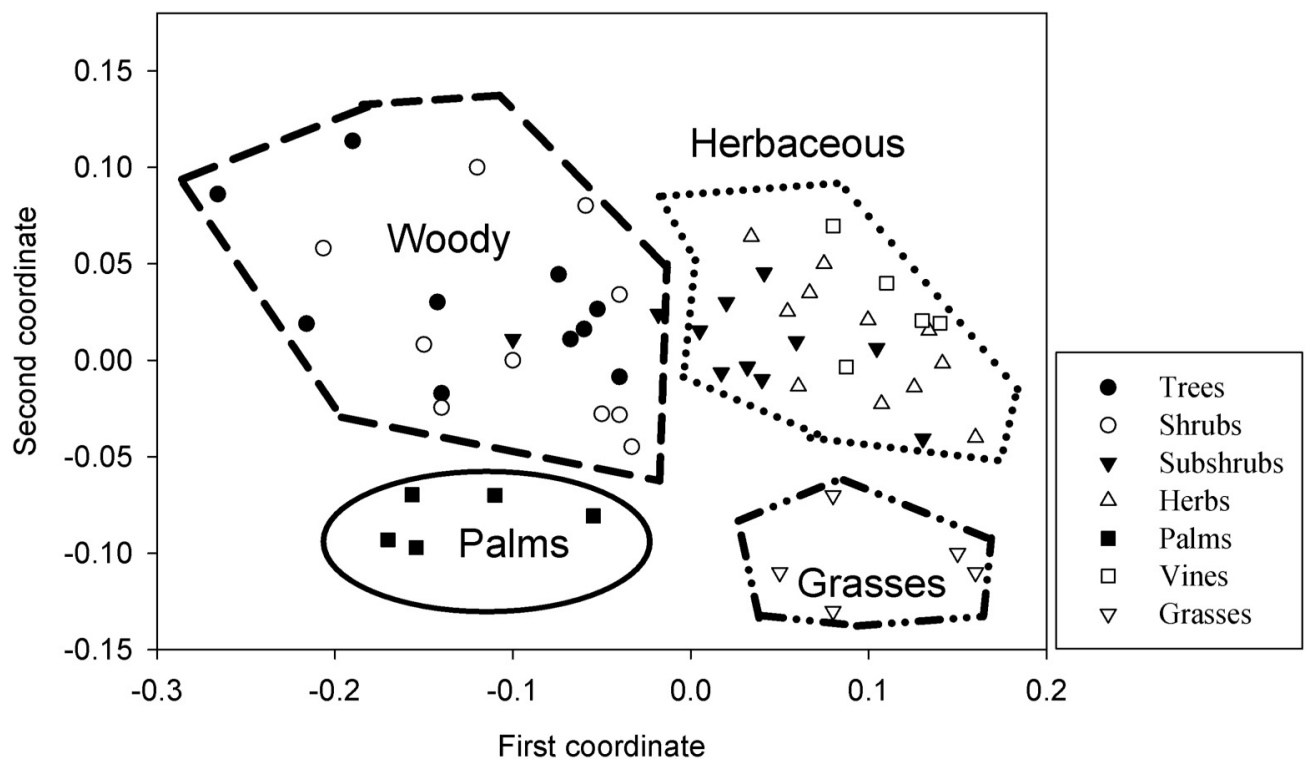

1979; Reich et al. 1999; Dahlgren et al. 2006; Castro-Díez et al. 2000; Delgado et al. 2013).

Based on the well-known trade-offs proposed on the concept of leaf economic spectrum (Wright et al. 2004), Cerrado grasses and herbs, with their low LMA values and their mesomorphic leaf traits, should have leaves with a short life-span, which is consistent with their assimilative activity being mostly restricted to the wet season, when water is readily available. Moreover, grasses and herbs would be subjected to moderate shading by the woody layer and would need to grow fast at the start of the rainy season or after a fire event, to make use of the high irradiances resulting from the opening of the upper canopy as leaves and many tree branches are burnt or damaged by the hot air flow during the fire or are lost during the dry season (Bond et al. 2003).

Despite showing similar set of leaf anatomical traits, grasses and herbs of the present study are not expected to strongly compete for soil resources, as it has been shown that they exploit different water and nutrient niches in the soil profile (Rossatto et al. 2013b). However, herbs would be subjected to strong competition with grasses for aboveground space occupancy. The expected higher leaf photosynthetic rates of $\mathrm{C}_{4}$ savanna grasses suggest they would grow faster than savanna herbs, being better competitors for space occupancy, which may explain their dominance in terms of biomass in the ground-layer vegetation (Scholes and Archer 1997).

Palms and vines are rarely cited as components of savannas; however, the Cerrado of Brazil has a high number of species (Mendonça et al. 2008). Based on the anatomical syndrome, vines showed anatomical adaptations similar to herbs. Vines occupy the intermediate stratum in the savanna. These climbers grow close to the ground and rarely under the trees. In contrast, given their larger plant size, palms were more closely related to trees and shrubs in terms of leaf anatomy. However, they differed from the latter on qualitative aspects of leaf structure, which are determined by their distinct phylogenetic position among the Angiosperms.

\section{Conclusions}

We were able to show that plant growth form and leaf structure are closely related. Co-occurring savanna plants of distinct growth forms could be grouped into different syndromes of leaf anatomical traits. Woody species (trees and shrubs) tend to produce thick, dorsiventral leaves with well-developed cuticles. Herbs and vines, in turn, tend to exhibit thinner leaves, with a mesomorphic set of leaf structures, while grasses and palms had homogenous mesophyll with sclerenchymatous bundle sheath extensions. However, grasses distinguished from palms by thinner leaves, lower ratios of mesophyll to leaf thickness, and a less developed cuticle, while palm leaves had a welldeveloped cuticle and sclerenchymatous hypodermis. Thus, Neotropical savannas cannot be exclusively described as a type of scleromorphic vegetation due to the large differences in leaf tissue anatomy of their distinct growth forms.

\section{Acknowledgements}

We thank Reserva Ecológica do IBGE, Brasília, DF Brazil, for logistic support. The Brazilian National Council of Research (CNPq) (Grant Nos. 141624/2009-4 and 484545/2012-4; 303637/2011-0) and Fundação de Amparo a Pesquisa do Estado de São Paulo (FAPESP) (Grant Nos. 2011/23112-3 and 2013/18049-6) supported this research.

\section{References}

Anten, N.P.R., Werger, M.J.A., and Medina, E. 1998. Nitrogen distribution and leaf area indices in relation to photosyn- 
thetic nitrogen use efficiency in savanna grasses. Plant Ecol. 138: 63-75. doi:10.1023/A:1009727822617.

Asner, G.P., Levick, S.R., Kennedy-Bowdoin, T., Knapp, D.E., Emerson, R., Jacobson, J., and Martin, R.E. 2009. Large-scale impacts of herbivores on the structural diversity of African savannas. Proc. Natl. Acad. Sci. U.S.A. 106(12): 4947-4952. doi: 10.1073/pnas.0810637106. PMID:19258457.

Bieras, A.C., and Sajo, M.G. 2009. Leaf structure of the cerrado (Brazilian savanna) woody plants. Trees, 23: 451-471. doi:10. 1007/s00468-008-0295-7.

Björkman, O. 1981. Responses to different quantum flux densities. In Encyclopaedia of plant physiology. Edited By O.L. Lange, P.S. Nobel, C.B. Osmond, and H. Ziegler. Springer, New York. pp. 57-107.

Bond, W.J., and Keeley, J.E. 2005. Fire as a global 'herbivore': the ecology and evolution of flammable ecosystems. Trends Ecol. Evol. 20: 387-394. doi:10.1016/j.tree.2005.04.025. PMID: 16701401.

Bond, W.J., Midgley, G.F., and Woodward, F.I. 2003. The importance of low atmospheric $\mathrm{CO} 2$ and fire in promoting the spread of grasslands and savannas. Glob. Chang. Biol. 9: 973982. doi:10.1046/j.1365-2486.2003.00577.x.

Bourliere, F. 1983. Tropical Savannas: Ecosystems of the World. Elsevier, Amsterdam, The Netherlands.

Castro-Díez, P., Puyravaud, J.P., and Cornelissen, J.H.C. 2000. Leaf structure and anatomy as related to leaf mass per area variation in seedlings of a wide range of woody plant species and types. Oecologia, 124: 476-786. doi:10.1007/PL00008873.

Cooper, S.M., and Owen-Smith, N. 1986. Effects of plant spinescence on large mammalian herbivores. Oecologia, 68: 446455. doi:10.1007/BF01036753.

Costa, A.N., Vasconcelos, H.L., Vieira-Neto, E.H.M., and Bruna, E.M. 2008. Do herbivores exert top-down effects in Neotropical savannas? Estimates of biomass consumption by leaf-cutter ants. J. Veg. Sci. 19: 849-854. doi:10.3170/2008-818461.

Dahlgren, J.P., Eriksson, O., Bolmgren, K., Strindell, M., and Ehrlen, J. 2006. Specific leaf area as a superior predictor of changes in field layer abundance during forest sucession. J. Veg. Sci. 17: 577-582. doi:10.1111/j.1654-1103.2006.tb02481.x.

Dansereau, P. 1951. Description and recording of vegetation upon a structural basis. Ecology, 32(2): 172-229. doi:10.2307| 1930415.

Delgado, M.N., Gomes, M.R., Bao, S.N., and Rossatto, D.R. 2013. Fertilisation residues alter leaf scleromorphy in an evergreen savannah shrub (Maprounea brasiliensis, Euphorbiaceae). Aust. J. Bot. 61: 266-273. doi:10.1071/BT12231.

Eiten, G. 1972. The Cerrado vegetation of central Brazil. Bot. Rev. 38: 201-341. doi:10.1007/BF02859158.

Evert, R.F. 2006. Esau's Plant Anatomy. Meristems, cells, and tissues of the plant body - their structure, function and development. Hoboken: Wiley and Sons.

Fahn, A., and Cutler, D. 1992. Xerophytes. Berlin: Gebrüder Borntraeger.

Felsenstein, J. 1985. Phylogenies and the comparative method. Am. Nat. 125: 1-15. doi:10.1086/284325.

Fensham, R.J., and Bowman, D.M.J.S. 1995. A comparison of foliar nutrient concentration in trees from monsoon rainforest and savanna in northern Australia. Aust. J. Ecol. 20: 335339. doi:10.1111/j.1442-9993.1995.tb00545.x.

Filgueiras, T.S. 2002. Herbaceous Plant Communities. In The Cerrados of Brazil: ecology and natural history of a neotropical savanna. Edited by P. Oliveira and R. Marquis. New York: Columbia University Press. pp. 121-140.

Franco, A.C. 2002. Ecophysiology of woody plants. In The Cerrados of Brazil: ecology and natural history of a neotropical savanna. Edited by P. Oliveira and R. Marquis. New York: Columbia University Press. pp. 178-197.
Franco, A.C., Lüttge, U. 2002. Midday depression in savanna trees: coordinated adjustments in photochemical efficiency, photorespiration, $\mathrm{CO} 2$ assimilation and water use efficiency. Oecologia, 131: 356-365. doi:10.1007/s00442-002-0903-y.

Franco, A.C., Bustamante, M., Caldas, L.S., Goldstein, G., Meinzer, F.C., Kozovits, A.R., Rundel, P., and Coradin, V.T.R. 2005. Leaf functional traits of neotropical savanna trees in relation to seasonal water deficit. Trees, 19: 326-335. doi:10. 1007/s00468-004-0394-z.

Franco, A.C., Matsubara, S., and Orthen, B. 2007. Photoinhibition, carotenoid composition and the co-regulation of photochemical and non-photochemical quenching in neotropical savanna trees. Tree Physiol. 27: 717-725. doi:10.1093/treephys/ 27.5.717. PMID:17267362.

Goodland, R. 1971. Oligotrofismo e alumínio no cerrado. In III Simpósio sobre o Cerrado. Edited by M.G. Ferri. São Paulo: Editora Edgard Blücher Ltda \& Editora da Universidade de São Paulo. pp. 44-60.

Gotelli, N.J., and Ellison, A.M. 2004. A primer of ecological statistics. Sinauer Associates, MA, U.S.A.

Gottsberger, G., and Silberbauer-Gottsberger, I. 2006. Life in the cerrado: a South American tropical seasonal ecosystem. Vol. I Origin, Structure, Dynamics and Plant use. Ulm: Reta Verlag.

Gratani, L., Covone, F., and Larcher, W. 2006. Leaf plasticity in response to light of three evergreen species of the Mediterranean maquis. Trees, 20: 549-558. doi:10.1007/s00468-0060070-6.

Grime, J.P. 1979. Plant strategies and vegetation process. London: Wiley.

Hammer, Ø., Harper, D.A.T., and Ryan, P.D. 2001. PAST: Paleontological statistics software package for education and data analysis. Palaeontol. Electron. 4(1): 9 pp.

Hauke, V., and Schreiber, L. 1998. Ontogenetic and seasonal development of wax composition and cuticular transpiration of ivy (Hedera helix L.) sun and shade leaves. Planta, 207: 67-75.

Hoffmann, W.A. 1996. The effects of cover and fire on seedling establishment in a Neotropical savanna. J. Ecol. 84: 383-393. doi:10.2307/2261200.

Hoffmann, W.A., Franco, A.C., Moreira, M.Z., and Haridasan, M. 2005. Specific leaf area explains differences in leaf traits between congeneric savanna and forest trees. Funct. Ecol. 19: 932-940. doi:10.1111/j.1365-2435.2005.01045.x.

Hoffmann, W.A., Adasme, R., Haridasan, M., Carvalho, M., Geiger, E.L., Pereira, M.A.B., Gotsch, S.G., and Franco, A.C. 2009. Tree topkill, not mortality, governs the dynamics of alternate stable states at savanna-forest boundaries under frequent fire in central Brazil. Ecology, 90: 1326-1337. doi:10. 1890/08-0741.1. PMID:19537552.

Hoffmann, W.A., Geiger, E.L., Gotsch, S., Rossatto, D.R., Silva, L.C.R., Lau, O.L., Haridasan, M., and Franco, A.C. 2012. Ecological thresholds at the savanna-forest boundary: How plant traits, resources and fire govern the distribution of tropical biomes. Ecol. Lett. 15: 759-768. doi:10.1111/j.1461-0248. 2012.01789.x. PMID:22554474.

Johansen, D.A. 1940. Plant microtechnique. New York: McGrawHill.

Keeley, J.E., Pausas, J.G., Rundel, P.W., Bond, W.J., and Bradstock, R.A. 2011. Fire as an evolutionary pressure shaping plant traits. Trends Plant Sci. 16(8): 406-441. doi:10.1016/j. tplants.2011.04.002. PMID:21571573.

Kraus, J.E., and Arduin, M. 1997. Manual básico de métodos em morfologia vegetal. Editora da Universidade Federal Rural do Rio de Janeiro, Seropedica.

Kraus, J.E., de Sousa, H.C., Rezende, M.H., Castro, N.M., Vecchi, C., and Luque, R. 1998. Astra blue and basic fuchsin double staining of plant materials. Biotech. Histochem. 73(5): 235-243. doi:10.3109/10520299809141117. PMID:9829416.

Krauss, P., Markstadter, C., and Riederer, M. 1997. Attenua- 
tion of UV radiation by plant cuticles from woody species. Plant Cell Environ. 20:1079-1085. doi:10.1111/j.1365-3040.1997. tb00684.x.

Larcher, W. 2003. Physiological plant ecology, 4th ed. New York: Springer.

Lehmann, C.E., Anderson, T.M., Sankaran, M., , et al. 2014. Savanna Vegetation-Fire-Climate Relationships Differ Among Continents. Science, 343: 548-552. doi:10.1126/science.1247355. PMID: 24482480.

Lison, L. 1960. Histochimie et cytochimie animals. GauthierVillars: Paris.

Marquis, R.J., Diniz, I.R., and Morais, H.C. 2001. Patterns and correlates of interspecific variation in foliar insect herbivory and pathogen attack in Brazilian cerrado. J. Trop. Ecol. 17: 127-148. doi:10.1017/S0266467401001080.

Mediavilla, S., Escudero, A., and Heilmeier, H. 2001. Internal leaf anatomy and photosynthetic resourse-use efficiency: interspecific and intraspecific comparisons. Tree Physiol. 21: 251259. doi:10.1093/treephys/21.4.251. PMID:11276419.

Mendonça, R.C., Felfili, J.M., Walter, B.M.T., Silva-Júnior, M.C., Rezende, A.B., Filgueiras, T.S., Nogueira, P.E., and Fagg, C.W. 2008. Flora Vascular do Bioma Cerrado: checklist com 12.356 espécies. In Cerrado: Ecologia e Flora. Vol. 2. Edited by S.M. Sano, S.P. Almeida, and J.F. Ribeiro. Brasília: Embrapa Cerrados. pp. 213-228.

Metcalf, C.R., and Chalk, L. 1979. Anatomy of the dicotyledons. Oxford: Clarendon Press.

Morretes, B.L. 1967. Contribuição ao estudo da anatomia das folhas de plantas do cerrado II. Boletim de Botânica da USP, 22: 209-244.

Morretes, B.L. 1969. Contribuição ao estudo da anatomia das folhas de plantas do cerrado III. Boletim de Botânica da USP, 24: 7-32.

Myers, N. 1990. The Biodiversity Challenge: Expanded Hot-Spots Analysis. Environmentalist, 10(4): 243-256. doi:10.1007/ BF02239720. PMID:12322583.

Niklas, K.J., Cobb, E.D., Niinemets, U., Reich, P.B., Sellin, A., Shipley, B., and Wright, I.J. 2007. "Diminishing returns" in the scalin of functional leaf traits across and within species groups. Proc. Natl. Acad. Sci. U.S.A. 104: 8891-8896. doi:10. 1073/pnas.0701135104. PMID:17502616.

Paiva, E.A.S., Isaias, R.M.S., Vale, F.H.A., and Queiroz, C.G.S. 2003. The influence of light intensity on anatomical structure and pigment contents of Tradescantia pallida (Rose) Hunt. cv. purpurea Boom (Commelinaceae) leaves. Braz. Arch. Biol. Technol. 46: 617-624. doi:10.1590/S1516-89132003000400017.

Pallardy, S.G. 1981. Closely related woody plants. In Water deficits and plant growth, Vol. VI. Edited by T.T. Kozlowski. New York: Academic Press. pp. 56-78.

Pausas, J.G., Bradstock, R.A., Keith, D.A., and Keeley, J.E. 2004. Plant functional traits in relation to fire in crown-fire ecosystems. Ecology, 85(4): 1085-1100. doi:10.1890/02-4094.

Prior, L.D., Eamus, D., and Bowman, D.M.J.S. 2004. Leaf attributes in the seasonally dry tropics: a comparison of four habitats in northern Australia. Funct. Ecol. 17: 504-515. doi: 10.1046/j.1365-2435.2003.00761.x.

Rasband, W.S. 1997-2012. ImageJ. National Institutes of Health, Bethesda, Maryland, U.S.A.

Read, J., Sanson,G. D. 2003. Characterizing Sclerophylly: The Mechanical Properties of a Diverse Range of Leaf Types. New Phytol. 160: 81-99. doi:10.1046/j.1469-8137.2003.00855.x.

Reich, P.B., Ellsworth, D.S., Walters, M.B., Vose, J.M., Gresham, C., Volin, J.C., and Bowman, W.D. 1999. Generality of leaf traits relationships: a test across six biomes. Ecology, 80: 1955-1969. doi:10.1890/0012-9658(1999)080[1955:GOLTRA] 2.0.CO;2.

Ribeiro, J.F., and Walter, B.M.T. 2008. Fitofisionomias do Bioma Cerrado. In Cerrado: Ecologia e flora. Edited by S.M. Sano, S.P.
Almeida, and J.F. Ribeiro. Planaltina: EMBRAPA Cerrados. pp. 19-45.

Riederer, M., and Schreiber, L. 2001. Protecting against water loss: analysis of the barrier properties of plant cuticles. J. Exp. Bot. 52(363): 2023-2032. doi:10.1093/jexbot/52.363.2023. PMID: 11559738.

Rossatto, D.R., and Kolb, R.M. 2010. Gochnatia polymorpha (Less.) Cabrera (Asteraceae) changes in leaf structure due to differences in light and edaphic conditions. Acta Bot. Bras. 24: 605-612. doi:10.1590/S0102-33062010000300002.

Rossatto, D.R., Hoffmann, W.A., and Franco, A.C. 2009. Características estomáticas de pares congenéricos de cerrado e mata de galeria crescendo numa região transicional no Brasil Central. Acta Bot. Bras. 23: 499-508. doi:10.1590/S010233062009000200021.

Rossatto, D.R., Hoffmann, W.A., Silva, L.C.R., Haridasan, M., Sternberg, L.S.L., and Franco, A.C. 2013a. Seasonal variation in leaf traits between congeneric savanna and forest trees in Central Brazil: implications for forest expansion into savanna. Trees, 27: 1139-1150. doi:10.1007/s00468-013-0864-2.

Rossatto, D.R., Sternberg, L.S.L., and Franco, A.C. 2013b. The partitioning of water uptake between growth forms in a Neotropical savanna: do herbs exploit a third water source niche? Plant Biol. 15: 84-92. doi:10.1111/j.1438-8677.2012. 00618.x. PMID:22672316.

Santiago, L.S., and Wright, S.J. 2007. Leaf functional traits of tropical forest plants in relation to growth form. Funct. Ecol. 21: 19-27. doi:10.1111/j.1365-2435.2006.01218.x.

Sarmiento, G., Goldstein, G., and Meinzer, F. 1985. Adaptative strategies of woody species in neotropical savannas. Biol. Rev. 60: 315-356. doi:10.1111/j.1469-185X.1985.tb00420.x.

Scholes, R.J., and Archer, S.R. 1997. Tree-grass interactions in savannas. Annu. Rev. Ecol. Syst. 28: 517-544. doi:10.1146/ annurev.ecolsys.28.1.517.

Sefton, C.A., Montagu, K., Atwell, B.J., and Conroy, J.P. 2002. Anatomical variation in juvenile eucalypt leaves accounts for differences in specific leaf area and $\mathrm{CO}_{2}$ assimilation rates. Aust. J. Bot. 50: 301-310. doi:10.1071/BT01059.

Skarpe, C. 1996. Plant functional types and climate in a southern African savanna. J. Veg. Sci. 7: 397-404. doi:10.2307/3236283.

The Angiosperm Phylogeny Group. 2009. An update of the Angiosperm Phylogeny Group classification for the orders and families of flowering plants: APG III. Bot. J. Linn. Soc. 161: 105-121. doi:10.1111/j.1095-8339.2009.00996.x.

Tjoelker, M.G., Craine, J.M., Wedin, D., Reich, P.B., and Tilman, D. 2005. Linking leaf and root trait syndromes among 39 grassland and savannah species. New Phytol. 167: 493-508. doi:10. 1111/j.1469-8137.2005.01428.x. PMID:15998401.

Tomlinson, K.W., Poorter, L., Sterck, F.J., Borghetti, F., Ward, D., de Bie, S., and van Langeveld, F. 2013. Leaf adaptations of evergreen and deciduous trees of semi-arid and humid savannas on three continents. J. Ecol. 101: 430-440. doi:10.1111/13652745.12056.

Vogelmann, T.C. 1993. Plant tissue optics. Annu. Rev. Plant Physiol. Plant Mol. Biol. 44: 231-251. doi:10.1146/annurev.pp. 44.060193.001311.

Westoby, M., and Wright, I.J. 2006. Land-plant ecology on the basis of functional traits. Trends Ecol. Evol. 21: 261-268. doi: 10.1016/j.tree.2006.02.004. PMID:16697912.

Wright, I.J., and Cannon, K. 2001. Relationships between leaf lifespan and structural defences in a low-nutrient, sclerophyllflora. FunctionalEcology, 15:351-359. doi:10.1046/j.13652435.2001.00522.x.

Wright, I.J., Reich, P.B., Westoby, M., Ackerly, D.D., Baruch, Z., Bongers, F., , and et al. 2004. The worldwide leaf economics spectrum. Nature, 428: 821-827. doi:10.1038/nature02403. PMID:15103368 
Copyright of Botany is the property of Canadian Science Publishing and its content may not be copied or emailed to multiple sites or posted to a listserv without the copyright holder's express written permission. However, users may print, download, or email articles for individual use. 